\title{
Diallel Analysis on Breast and Thigh Muscle Traits in the Cross of Three South African Indigenous Chicken Genotypes
}

\author{
Thobela L Tyasi*, Jones W Ng'ambi, and David Norris \\ School of Agricultural and Environmental Sciences, Department of Agricultural Economics and Animal Production, University of Limpopo, Private \\ Bag X1106, Sovenga 0727, Limpopo, South Africa \\ "Corresponding author's Email: louis.tyasi@ul.ac.za; ORCID: 0000-0002-3519-7806
}

Received: 15 Jan. 2021

Accepted: 28 Feb. 2021

\begin{abstract}
The present study aimed to estimate carcass characteristics of pure and crossbred chickens produced from three parental populations. A $3 \times 3$ complete diallel mating system involving three indigenous breeds, namely Potchefstroom Koekoek $(\mathrm{P})$, Venda $(\mathrm{V})$, and Ovambo $(\mathrm{O})$, was used to produce three purebred $(\mathrm{P} \times \mathrm{P}, \mathrm{V} \times \mathrm{V}, \mathrm{O} \times \mathrm{O})$, three crossbreds $(\mathrm{P} \times \mathrm{O}, \mathrm{P} \times \mathrm{V}, \mathrm{O} \times \mathrm{V})$ and three reciprocals $(\mathrm{O} \times \mathrm{P}, \mathrm{V} \times \mathrm{P}, \mathrm{V} \times \mathrm{O})$. The nine genetic groups were reared from hatch to 10 weeks of age in an open house with deep litter. At 10 weeks of age, six chickens per genetic group were randomly selected for slaughter. After slaughtering the breast and thigh muscles samples for analysis of the carcass characteristics (Meat colour, meat $\mathrm{pH}$, and Shear force). The results showed that the Potchefstroom Koekoek breed had higher values in all colour indicators, L* (lightness), a* (redness), and b* (yellowness), compared to the other chicken breeds. The Potchefstroom Koekoek and $\mathrm{P} \times \mathrm{O}$ breed had higher $\mathrm{pH}$ values ranging from 5.66 to 6 at two hours post-slaughter and from 5.54 to 6.38 at 24 hours post-slaughter. The pH declines in all the nine genetic groups after two to 24 hours, with the exception of the crossbred $\mathrm{P} \times \mathrm{O}$, which increased from 6.06 to 6.38 . In terms of shear force, the $\mathrm{O} \times \mathrm{P}$ had the highest shear value, ranging from $35.89 \mathrm{~N}$ to $74.80 \mathrm{~N}$, compared to other genetic groups. Potchefstroom Koekoek had normal meat colour and $\mathrm{pH}$, whereas the Venda breed had tougher meat than other genotypes. The results of the present study might be useful for local chicken farmers to improve carcass traits.
\end{abstract}

Keywords: Crossbred, Meat colour, Meat pH, Purebred, Shear force.

\section{INTRODUCTION}

Diallel cross is the crossbreeding among several genotypes and data analysis from such crosses (Khalil and Khadiga, 2020). Crossbreeding is one of the tools that can be used in genetic variation (Wang et al., 2019). This crossbreeding which is the mating of two individuals with different breed compositions, is one type of a larger class of mating systems known as out-breeding (Khalil and Khadiga, 2020). There are many South African indigenous chicken genotypes, including Potchefstroom Koekoek, Venda, and Ovamba chicken (Manyelo et al., 2020). The Potchefstroom Koekoek chicken genotype, developed by crossing Black Australorp cockerels with White Leghorn hens and Plymouth Rock, reaches sexual maturity after 130 days and is mainly categorized by black and white speckled colour patterns (Mutibvu et al., 2020). The Venda chicken genotype, discovered in the Venda region of South Africa, is a dual-purpose breed with multi- coloured patterns predominated by black and white colours (Manyelo et al., 2020). On the other hand, the Ovambo chicken genotype, first discovered in the Ovamboland of northern Namibia, is predominantly dark to black in colour and can reach sexual maturity after 140 days (Mutibvu et al., 2020). Tyasi et al. (2019) conducted a diallel cross of three South African indigenous chicken genotypes, namely chicken genotypes Potchefstroom Koekoek, Venda, and Ovamba, to investigate the crossbreeding effects on growth traits. Thus far, there had been limited studies of the crossbreeding effects on breast and thigh muscles in Potchefstroom Koekoek, Ovambo, and Venda chicken breeds. Hence, the objective of the study was to determine the effect of crossbreeding on meat $\mathrm{pH}$, meat colour and meat tenderness on breast and thigh muscle traits. The current study will aid indigenous chicken farmers to improve carcass characteristics through crossbreeding. 


\section{MATERIALS AND METHODS}

\section{Ethical approval}

This research was carried out in accordance with the standard operation procedures of the Animal Research and Ethics Committee (AREC) at the University of Limpopo, South Africa.

\section{Study area}

The present study was conducted on the experimental farm of the University of Limpopo in the Limpopo Province of South Africa. The farm is located about 10 kilometers northwest of the university. The mean temperatures in winter (April to July) range between 10.1 and $28.4{ }^{\circ} \mathrm{C}$ and in summer (August to March) between 18 and $36{ }^{\circ} \mathrm{C}$. The annual rainfall ranges between 446.8 and $468.4 \mathrm{~mm}$.

\section{Preparation of the house}

The house was prepared as explained in Alabi et al. (2020). Briefly, the incubator and all the equipment such as drinkers, feeders, and wire separators were thoroughly cleaned and disinfected.

\section{Chickens management}

Ten hens of each breed were assigned randomly to be mated with two roosters of each breed. The eggs were collected daily by breeds and crossbreds and then hatched separately according to breeds and crossbreds. Accordingly, nine genetic groups of $\mathrm{P} \times \mathrm{P}, \mathrm{V} \times \mathrm{V}, \mathrm{O} \times \mathrm{O}$, $\mathrm{P} \times \mathrm{V}, \mathrm{P} \times \mathrm{N}, \mathrm{V} \times \mathrm{P}, \mathrm{V} \times \mathrm{O}, \mathrm{O} \times \mathrm{P}$, and $\mathrm{O} \times \mathrm{V}$ chickens were obtained. The hatched chickens were wing banded until eight weeks of age, followed by leg bands to keep their breed and crossbred group identity. The chickens were kept together on a litter floor in a semi-open house, which was partitioned according to their breeds and crossbreds. They were medicated in a similar way and were subjected to the same management, hygiene, and climatic conditions. During the brooding and rearing periods, all chickens were fed ad libitum using a standard commercial starter $(21 \%$ Crude Protein (CP) and 3,000 kcal Metabolizable Energy (ME)/kg) from hatching time until four weeks of age, followed by a grower diet (18\% $\mathrm{CP}$ and 2,900 kcal ME/kg) up to ten weeks of age. Water was provided ad libitum. Artificial heat $\left(32{ }^{\circ} \mathrm{C}\right)$ using infrared lights and a continuous light program was provided. The ventilation was controlled using curtain rails.

\section{Meat pH measurements}

A portable $\mathrm{pH}$ meter with a fibre-optic probe (CRISON pH 25 Instruments S.A., Alella, Spain) was used to measure the $\mathrm{pH}$ ( $\mathrm{pH} 2$ and 24 hours post mortem) of the carcasses. The $\mathrm{pHu}$ was first calibrated using standard solutions of $\mathrm{pH} \mathrm{4,} \mathrm{pH} \mathrm{7,} \mathrm{and} \mathrm{pH} 9$ (CRISON Instruments, SA, and Spain). The measurements were then performed with a sharpened metal sheath to prevent probe breakage due to the raw meat contamination.

\section{Determination of meat colour}

The colour of the meat ( $\mathrm{L}^{*}$ : Lightness, $\mathrm{a}^{*}$ : Redness, and $\mathrm{b}^{*}$ : Yellowness) was determined two hours after slaughter (Commission International De I' Eclairage, 1976). A refrigerated portable vehicle was used to move the carcass from the slaughtering place to the University of Limpopo, Department of Animal Production laboratory one hour after the slaughter. A Minolta colour-guide 45/0 BYK-Gardener $\mathrm{GmbH}$ machine with a $20 \mathrm{~mm}$ diameter measurement and an illuminant D65-daylight, from 100 standard observers was used for the colour measurement. The machine was calibrated each time before measurements were taken using the standard green, black and white colour samples provided for this purpose. The readings were taken by rotating the Colour Guide 900 between measurements to obtain the average value for the colour.

\section{Determination of meat tenderness}

The tenderness of the chicken was determined using the Instron- Warner-Bratzler Shear Force (WBSF). After cooking, subsamples of specified core diameter were cored parallel to the grain of the meat. Three subsamples with a core diameter of $10 \mathrm{~mm}$ were cored parallel to the grain of the meat. The samples were sheared perpendicular to the fiber direction using a Warner Bratzler (WB) shear device mounted on an Instron (Model 3344) Universal Testing apparatus (the crosshead speed at $400 \mathrm{~mm} /$ minutes, one shear of each core). The mean maximum load (N) was recorded for the batch.

\section{Data analysis}

The Generalized Linear Models procedure (PROC GLM) of Statistical Analysis System (SAS, 2019), version 9.4, was used to determine the effect of the chicken genotype on the chicken quality attributes $\left(\mathrm{pH}, \mathrm{L}^{*}, \mathrm{a}^{*}, \mathrm{~b}^{*}\right.$ and WBSF values).

$$
\mathrm{Y} \mathrm{i}=\mu+\alpha \mathrm{i}+\varepsilon \mathrm{i}
$$

Where, 
$\mathrm{Yi}=$ Response variable ( $\mathrm{pH}, \mathrm{L}, \mathrm{a}^{*}, \mathrm{~b}^{*}$ and WBSF), $\mu$ is the overall mean, $\alpha$ i denoted breed effect $(\mathrm{V} \times \mathrm{V}, \mathrm{O} \times \mathrm{O}$, $\mathrm{P} \times \mathrm{P}, \mathrm{V} \times \mathrm{O}, \mathrm{V} \times \mathrm{P}, \mathrm{O} \times \mathrm{V}, \mathrm{O} \times \mathrm{P}, \mathrm{P} \times \mathrm{V}$ and $\mathrm{P} \times \mathrm{O}$ genotypes), and $\varepsilon i$ refers to random error term. Differences considered significant $(\mathrm{p} \leq 0.05)$ were compared with Fisher's protected Least Significant Difference (LSD test).

\section{RESULTS}

The meat colour of different genotypes for the breast muscle is presented in Table 1 . The results showed a significant difference $(p<0.05)$ in the colour of the breast muscle between the nine genetic groups. In terms of lightness, the Ovambo chicken genotype had a higher value, followed by $\mathrm{O} \times \mathrm{V}$ chicken genotype. However, there were no statistically significant differences $(p>0.05)$ between crosses $(\mathrm{P} \times \mathrm{O}, \mathrm{P} \times \mathrm{V}$, and $\mathrm{O} \times \mathrm{V})$ and reciprocals $(\mathrm{V} \times \mathrm{P}, \mathrm{V} \times \mathrm{O}$, and $\mathrm{O} \times \mathrm{P})$. For redness, the Potchefstroom Koekoek genotype had a higher value $(\mathrm{p}<0.05)$ followed by the $\mathrm{P} \times \mathrm{O}$ chicken genotype. The results also indicated that $\mathrm{O} \times \mathrm{V}$ had statistically insignificant differences $(\mathrm{p}>$ 0.05 ) with reciprocals $(\mathrm{V} \times \mathrm{P}, \mathrm{V} \times \mathrm{O}$, and $\mathrm{O} \times \mathrm{P})$ as well as $\mathrm{V} \times \mathrm{V}$ and $\mathrm{P} \times \mathrm{V}$. In yellowness, the Potchefstroom Koekoek chicken genotype also had a higher value $(\mathrm{p}<$ 0.05) than the other chicken genotypes. The results showed that there were no statistically significant differences $(\mathrm{p}>0.05)$ between $\mathrm{V} \times \mathrm{V}$ and crosses $(\mathrm{P} \times \mathrm{O}$, $\mathrm{P} \times \mathrm{V}$, and $\mathrm{O} \times \mathrm{V})$. These results also indicated that there were no remarkable differences $(\mathrm{p}>0.05)$ between $\mathrm{V} \times \mathrm{V}$ and the reciprocal values $(\mathrm{O} \times \mathrm{P}, \mathrm{V} \times \mathrm{P})$.

Table 2 shows a meat colour of different genotypes for the thigh muscle. The results showed a significant difference $(\mathrm{p}<0.05)$ in thigh muscle colour between the nine genetic groups. In terms of lightness, Potchefstroom Koekoek genotype, and Venda chicken genotype had a higher value $(\mathrm{p}<0.05)$, followed by Ovambo chicken genotype and the crosses $(\mathrm{P} \times \mathrm{O}, \mathrm{P} \times \mathrm{V}$, and $\mathrm{O} \times \mathrm{V})$ chicken genotypes. However, no statistically significant differences $(\mathrm{p}>0.05)$ between reciprocals $(\mathrm{V} \times \mathrm{P}, \mathrm{V} \times \mathrm{O}$, $\mathrm{O} \times \mathrm{P})$ were observed. In redness, The findings recognized that no statistically significant differences $(p>0.05)$ were observed between $\mathrm{P} \times \mathrm{P}, \mathrm{O} \times \mathrm{O}$ purebreds, $\mathrm{P} \times \mathrm{O}, \mathrm{P} \times \mathrm{V}$, $\mathrm{O} \times \mathrm{V}$ crosses, and $\mathrm{V} \times \mathrm{O}$ reciprocal. In yellowness, the Potchefstroom Koekoek chicken genotype had a higher value $(\mathrm{p}<0.05)$ than the other chicken genotypes. The results also showed that there were no statistically significant differences $(\mathrm{p}>0.05)$ between $\mathrm{O} \times \mathrm{O}, \mathrm{V} \times \mathrm{V}$, and $\mathrm{O} \times \mathrm{V}$ cross and $\mathrm{O} \times \mathrm{P}$ reciprocal.

The meat $\mathrm{pH}$ values of breast muscle at 2 and 24 hours post-mortem in purebreds, crossbreds, and reciprocals are presented in Figure 1. At a pH of 2 hours post-mortem, the findings indicated that the cross of $\mathrm{P} \times \mathrm{O}$ had a higher $\mathrm{pH}$ value $(5.70 \pm 0.09)(\mathrm{p}<0.05)$ than the other genetic groups. The results indicated that no statistically significant differences $(\mathrm{p}>0.05)$ between purebreds' $\mathrm{P} \times \mathrm{P}(5.66 \pm 0.01), \mathrm{O} \times \mathrm{O}(5.61 \pm 0.02)$, and $\mathrm{V}$ $\times \mathrm{V}(5.64 \pm 0.03)$ were observed. The results also recognized that there were no remarkable differences $(\mathrm{p}>$ $0.05)$ between the reciprocal genetic groups $\mathrm{O} \times \mathrm{P}(5.57 \pm$ $0.16), \mathrm{V} \times \mathrm{P}(5.52 \pm 0.02)$, and $\mathrm{V} \times \mathrm{O}(5.55 \pm 0.01)$ were observed. At a $\mathrm{pH}$ of 24 hours post-mortem, the results indicated that the Potchefstroom Koekoek chicken genotype had a higher $\mathrm{pH}$ value $(5.64 \pm 0.03)(\mathrm{p}<0.05)$ than the other chicken genotypes. The results indicated that there were no statistically significant differences $(\mathrm{p}>$ $0.05)$ between reciprocal genetic groups $\mathrm{O} \times \mathrm{P}(5.47 \pm$ $0.04), \mathrm{V} \times \mathrm{P}(5.53 \pm 0.02)$, and $\mathrm{V} \times \mathrm{O}(5.47 \pm 0.04)$, were observed.Meat $\mathrm{pH}$ of thigh muscle at 2 and 24 hours' postmortem in purebreds, crossbreds, and reciprocals is presented in Figure 2. At a pH of 2 hours post-mortem, the results showed that the cross of $\mathrm{P} \times \mathrm{O}$ had a higher $\mathrm{pH}$ value $(6.06 \pm 0.07)(\mathrm{p}<0.05)$ than the other genetic groups. The results indicated that there were no remarkable differences $(\mathrm{p}>0.05)$ between purebreds' $\mathrm{P} \times$ $\mathrm{P}(6.00 \pm 0.04)$, and $\mathrm{V} \times \mathrm{V}(5.98 \pm 0.08)$, and reciprocal $\mathrm{V}$ $\times \mathrm{P}(5.96 \pm 0.06)$ chicken genotype were observed. At a $\mathrm{pH}$ of 24 hours post-mortem, the findings recognized that the cross of $\mathrm{P} \times \mathrm{O}$ chicken genotype had a higher $\mathrm{pH}$ value $(5.70 \pm 0.09)(\mathrm{p}<0.05)$ than the other chicken genotypes. There were no statistically significant differences $(\mathrm{p}>$ $0.05)$ between $\mathrm{V} \times \mathrm{V}(5.98 \pm 0.08)$, cross $\mathrm{O} \times \mathrm{V}(5.83 \pm$ $0.07)$, and reciprocals $\mathrm{V} \times \mathrm{P}(5.96 \pm 0.06)$ and $\mathrm{V} \times \mathrm{O}(5.90$ \pm 0.03 ) were observed.

Table 3 shows the results of the shear force for thigh and breast muscles. In purebreds, the results showed that $P$ $\times \mathrm{P}$ had a higher shear force value as compared with other purebreds but there were no statistically significant differences $(\mathrm{p}>0.05)$ between $\mathrm{P} \times \mathrm{P}$ and $\mathrm{O} \times \mathrm{O}$ in thigh muscle. Whereas in breast muscle, there were no statistically significant differences $(p>0.05)$ observed between purebreds. In crosses, the findings indicated that there were no statistically significant differences among all crosses $(\mathrm{p}>0.05)$. While in breast muscle, $\mathrm{O} \times \mathrm{V}$ had a higher shear force value $(\mathrm{p}<0.05)$ followed by $\mathrm{O} \times \mathrm{V}$, respectively. With respect to reciprocals, $\mathrm{V} \times \mathrm{O}$ had a higher shear force value $(\mathrm{p}<0.05)$ but no statistically significant differences $(\mathrm{p}>0.05)$ observed between $\mathrm{O} \times \mathrm{P}$ and $\mathrm{V} \times \mathrm{P}$. However, in breast muscle, there were no statistically significant differences $(p>0.05)$ detected between $\mathrm{O} \times \mathrm{P}$ and $\mathrm{V} \times \mathrm{O}$, respectively. 
Table 1. Meat colour of breast muscle in purebreds, crosses, and reciprocals of three South African indigenous chicken genotypes (Potchefstroom Koekoek, Ovambo, and Venda)

\begin{tabular}{|c|c|c|c|c|}
\hline Genotypes & & $\mathbf{L}^{*}$ & $\mathbf{a}^{*}$ & $\mathbf{b}^{*}$ \\
\hline \multirow{3}{*}{ Purebreds } & $\mathrm{P} \times \mathrm{P}$ & $43.56 \pm 0.02^{\mathrm{d}}$ & $9.39 \pm 0.51^{\mathrm{a}}$ & $10.68 \pm 0.88^{a}$ \\
\hline & $\mathrm{O} \times \mathrm{O}$ & $56.54 \pm 1.50^{\mathrm{a}}$ & $1.68 \pm 0.30^{\mathrm{e}}$ & $6.69 \pm 0.61^{\mathrm{c}}$ \\
\hline & $\mathrm{V} \times \mathrm{V}$ & $44.79 \pm 0.89^{\mathrm{cd}}$ & $5.13 \pm 0.81^{\mathrm{cd}}$ & $9.15 \pm 0.77^{\mathrm{abc}}$ \\
\hline \multirow{3}{*}{ Crosses } & $\mathrm{P} \times \mathrm{O}$ & $48.03 \pm 3.09^{\text {bcd }}$ & $6.51 \pm 0.43^{b}$ & $8.96 \pm 0.90^{\mathrm{abc}}$ \\
\hline & $\mathrm{P} \times \mathrm{V}$ & $47.41 \pm 0.38^{b c}$ & $6.43 \pm 0.29^{b c}$ & $8.99 \pm 0.84^{\mathrm{abc}}$ \\
\hline & $\mathrm{O} \times \mathrm{V}$ & $50.93 \pm 2.45^{\mathrm{b}}$ & $4.90 \pm 0.29^{\mathrm{cd}}$ & $9.36 \pm 1.11^{\mathrm{ab}}$ \\
\hline \multirow{3}{*}{ Reciprocals } & $\mathrm{O} \times \mathrm{P}$ & $48.84 \pm 2.35^{\mathrm{bc}}$ & $5.05 \pm 0.65^{\mathrm{cd}}$ & $7.44 \pm 1.22^{\mathrm{bcc}}$ \\
\hline & $\mathrm{V} \times \mathrm{P}$ & $46.93 \pm 0.55^{c}$ & $4.02 \pm 0.38^{\mathrm{d}}$ & $7.60 \pm 1.22^{\mathrm{bcc}}$ \\
\hline & $\mathrm{V} \times \mathrm{O}$ & $47.64 \pm 0.11^{\mathrm{bcd}}$ & $3.75 \pm 0.47^{\mathrm{d}}$ & $5.13 \pm 1.11^{\mathrm{d}}$ \\
\hline
\end{tabular}

$\stackrel{\bar{a}-\mathrm{d}}{\mathrm{a}}$ : Means in the same column with the same letters did not differ significantly (p > 0.05), P $\times$ P: Potchefstroom Koekoek, O $\times$ O: Ovambo, V $\times$ V: Venda, L*: Lightness, $a^{*}$ : Redness, $b^{*}$ : Yellowness.

Table 2. Meat colour of thigh muscle in purebreds, crosses, and reciprocals of three South African indigenous chicken genotypes (Potchefstroom Koekoek, Ovambo, and Venda).

\begin{tabular}{|c|c|c|c|c|}
\hline Genotypes & & $\mathbf{L}^{*}$ & $\mathbf{a}^{*}$ & $\mathbf{b}^{*}$ \\
\hline \multirow{3}{*}{ Purebreds } & $\mathrm{P} \times \mathrm{P}$ & $52.09 \pm 1.12^{\mathrm{a}}$ & $8.95 \pm 0.58^{\mathrm{a}}$ & $12.87 \pm 1.16^{\mathrm{a}}$ \\
\hline & $\mathrm{O} \times \mathrm{O}$ & $46.29 \pm 0.59^{b}$ & $8.54 \pm 0.53^{\mathrm{a}}$ & $9.26 \pm 0.31^{\mathrm{b}}$ \\
\hline & $\mathrm{V} \times \mathrm{V}$ & $50.83 \pm 0.36^{\mathrm{a}}$ & $6.47 \pm 0.53^{\mathrm{c}}$ & $7.36 \pm 1.59^{\mathrm{bc}}$ \\
\hline \multirow{3}{*}{ Crosses } & $\mathrm{P} \times \mathrm{O}$ & $45.92 \pm 0.93^{b}$ & $8.06 \pm 1.15^{\mathrm{a}}$ & $6.56 \pm 2.08^{c}$ \\
\hline & $\mathrm{P} \times \mathrm{V}$ & $43.11 \pm 0.74^{b}$ & $8.74 \pm 0.62^{\mathrm{a}}$ & $4.53 \pm 0.78^{\mathrm{d}}$ \\
\hline & $\mathrm{O} \times \mathrm{V}$ & $45.67 \pm 1.11^{\mathrm{b}}$ & $8.00 \pm 1.37^{\mathrm{a}}$ & $7.77 \pm 2.04^{b c}$ \\
\hline \multirow{3}{*}{ Reciprocals } & $\mathrm{O} \times \mathrm{P}$ & $46.80 \pm 0.71^{b}$ & $7.43 \pm 0.36^{\mathrm{b}}$ & $7.03 \pm 0.77^{\mathrm{bc}}$ \\
\hline & $\mathrm{V} \times \mathrm{P}$ & $46.60 \pm 0.82^{b}$ & $6.78 \pm 0.11^{\mathrm{bc}}$ & $6.81 \pm 1.40^{c}$ \\
\hline & $\mathrm{V} \times \mathrm{O}$ & $47.55 \pm 0.45^{\mathrm{b}}$ & $8.30 \pm 0.32^{\mathrm{a}}$ & $6.27 \pm 1.62^{\mathrm{c}}$ \\
\hline
\end{tabular}

${ }^{\mathrm{a}-\mathrm{d}}$ Means in the same column with the same letters did not significantly differ (p > 0.05), P $\times$ P: Potchefstroom Koekoek, O $\times$ O: Ovambo, V $\times$ V: Venda, L*: Lightness, a*: Redness, $b^{*}$ : Yellowness.

Table 3. Comparison of shear force in purebreds, crosses, and reciprocals of three South African indigenous chicken genotypes (Potchefstroom Koekoek, Ovambo, and Venda).

\begin{tabular}{|c|c|c|c|}
\hline Conotunes & & Thigh WBSF & Breast WBSF \\
\hline \multirow{3}{*}{ Purebreds } & $\mathrm{P} \times \mathrm{P}$ & $44.15 \pm 7.45^{\mathrm{a}}$ & $58.82 \pm 5.92^{\mathrm{c}}$ \\
\hline & $\mathrm{O} \times \mathrm{O}$ & $40.50 \pm 6.78^{\mathrm{ab}}$ & $51.94 \pm 3.87^{\mathrm{cd}}$ \\
\hline & $\mathrm{V} \times \mathrm{V}$ & $32.50 \pm 1.55^{\mathrm{bc}}$ & $59.07 \pm 2.81^{c}$ \\
\hline \multirow{3}{*}{ Crosses } & $\mathrm{P} \times \mathrm{O}$ & $31.38 \pm 2.04^{\mathrm{bc}}$ & $55.51 \pm 9.64^{c}$ \\
\hline & $\mathrm{P} \times \mathrm{V}$ & $29.25 \pm 2.01^{\mathrm{c}}$ & $43.62 \pm 0.64^{\mathrm{d}}$ \\
\hline & $\mathrm{O} \times \mathrm{V}$ & $31.73 \pm 3.05^{\mathrm{bc}}$ & $61.23 \pm 4.36^{\mathrm{b}}$ \\
\hline \multirow{3}{*}{ Reciprocals } & $\mathrm{O} \times \mathrm{P}$ & $35.89 \pm 1.36^{\mathrm{b}}$ & $74.80 \pm 7.15^{\mathrm{a}}$ \\
\hline & $\mathrm{V} \times \mathrm{P}$ & $42.33 \pm 3.56^{\mathrm{ab}}$ & $65.41 \pm 6.35^{\mathrm{b}}$ \\
\hline & $\mathrm{V} \times \mathrm{O}$ & $46.09 \pm 6.36^{\mathrm{a}}$ & $72.34 \pm 8.26^{\mathrm{a}}$ \\
\hline
\end{tabular}

${ }^{\mathrm{a}-\mathrm{d}}$ Means with the same column with the same letters did not significantly differ (p>0.05), P $\times$ P: Potchefstroom Koekoek, $\mathrm{O} \times \mathrm{O}:$ Ovambo, V $\times$ V: Venda. WBSF: Warner Braztler Shear Force 


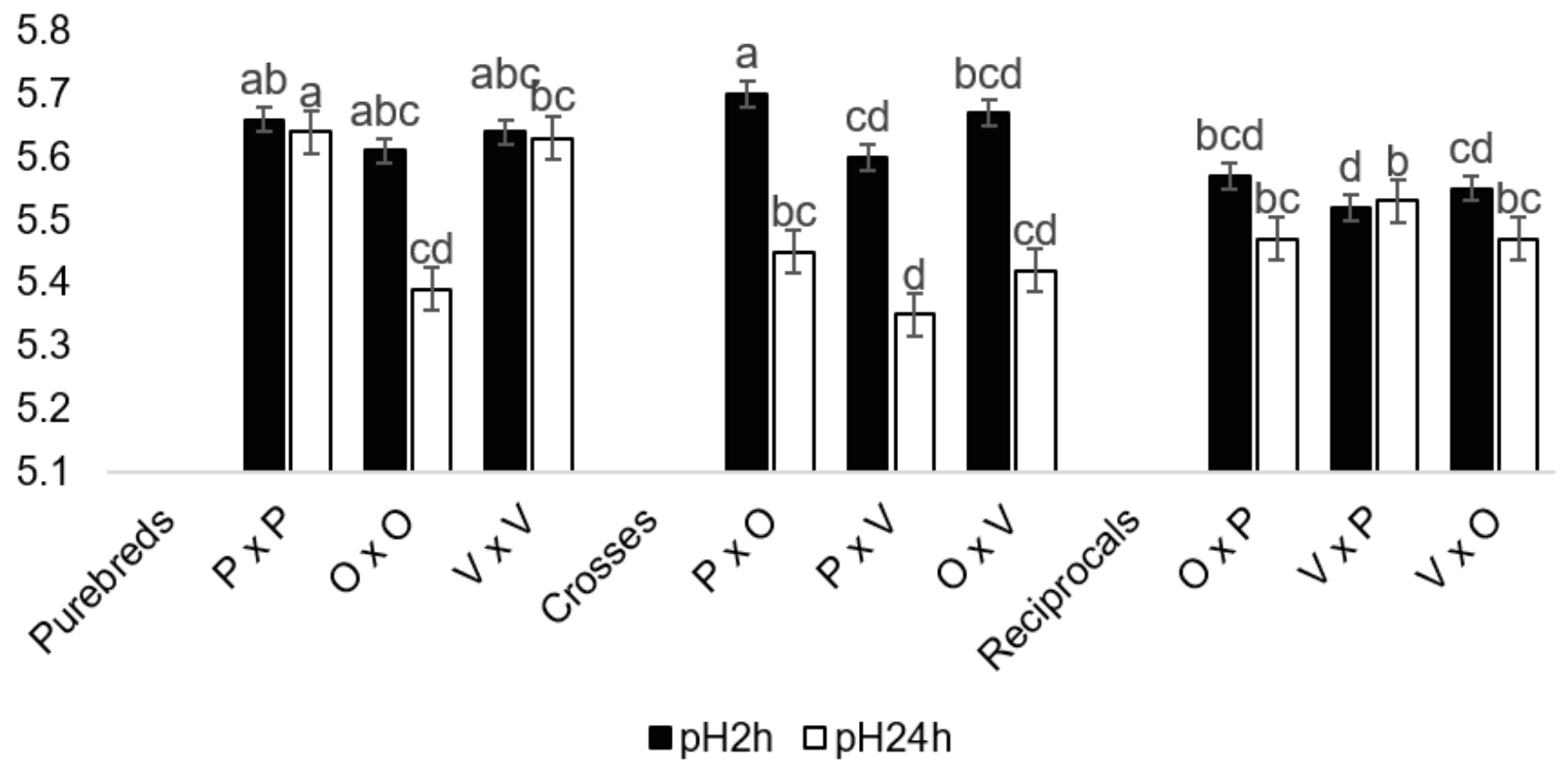

Figure 1. Meat $\mathrm{pH}$ of breast muscle 2 and 24 hours in purebreds, crosses, and reciprocals of three South African indigenous chicken genotypes. ${ }^{\mathrm{a}-\mathrm{d}}$ : Means that the same column with the same letters did not significantly differ $(\mathrm{p}>0.05), \mathrm{P} \times \mathrm{P}$ : Potchefstroom Koekoek, $\mathrm{O} \times \mathrm{O}$ : Ovambo, $\mathrm{V} \times \mathrm{V}$ : Venda, $\mathrm{pH}_{2 \mathrm{~h}}=\mathrm{pH} 2$ hours post-mortem, $\mathrm{pH}_{24 \mathrm{~h}}=\mathrm{pH} 24$ hours post-mortem.

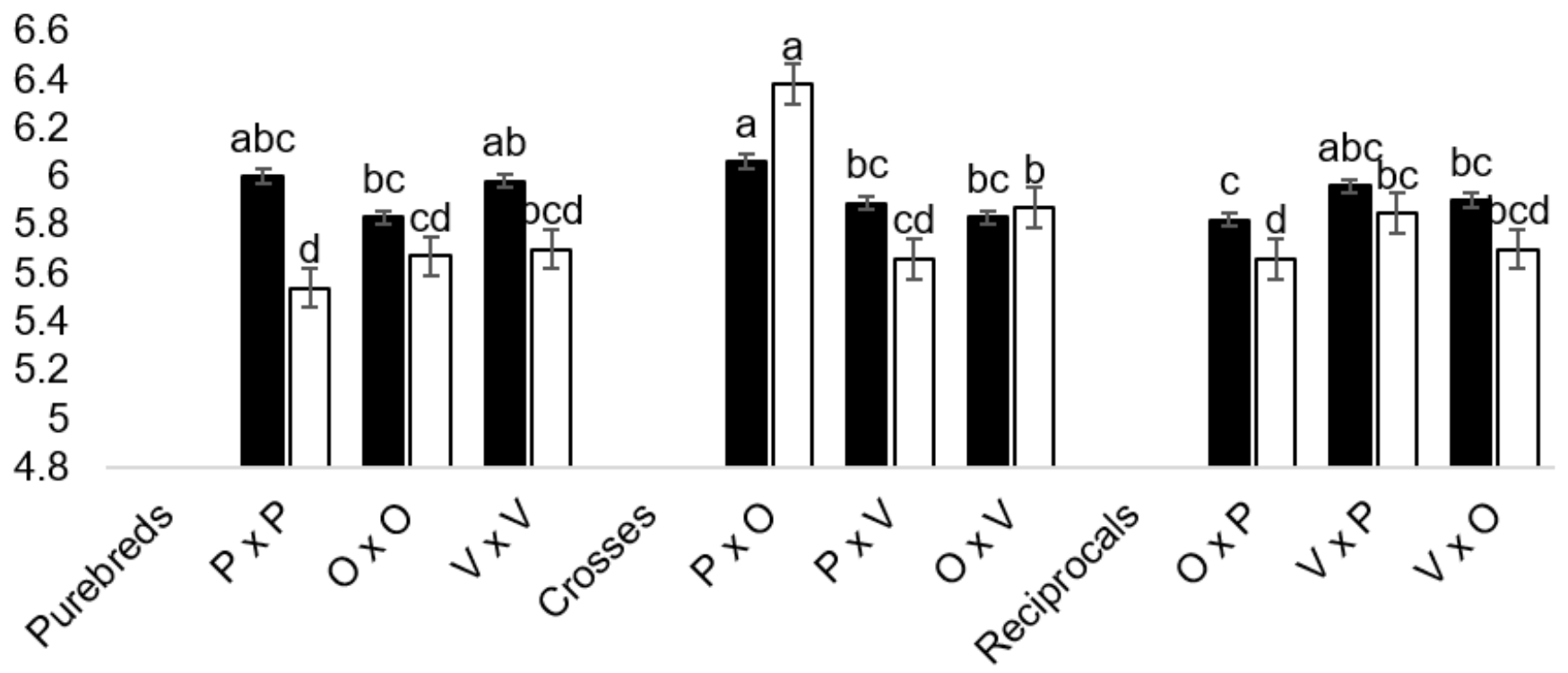

\section{- $\mathrm{pH} 2 \mathrm{~h} \quad \mathrm{p} \mathrm{p} 24 \mathrm{~h}$}

Figure 2. Meat $\mathrm{pH}$ of thigh muscle at 2 and 24 hours in purebreds, crosses, and reciprocals of three South African indigenous chicken genotypes. ${ }^{\mathrm{a}-\mathrm{d}}$ : Means with the same column with the same letters did not significantly differ $(\mathrm{p}>0.05), \mathrm{P} \times \mathrm{P}$ : Potchefstroom Koekoek, $\mathrm{O} \times \mathrm{O}$ : Ovambo, $\mathrm{V} \times \mathrm{V}$ : Venda, $\mathrm{pH}_{2 \mathrm{~h}}=\mathrm{pH} 2$ hours' post-mortem, $\mathrm{pH}_{24 \mathrm{~h}}=\mathrm{pH} 24$ hours' postmortem. 


\section{DISCUSSION}

Crossbreeding may possibly be used to achieve genetic improvement with or without genetic selection in the parental lines (Wang et al., 2019). The influence of crossbreeding on meat color, $\mathrm{pH}$, and tenderness in breast and thigh muscles of nine genetic groups namely; purebreds $(\mathrm{P} \times \mathrm{P}, \mathrm{O} \times \mathrm{O}, \mathrm{V} \times \mathrm{V})$, crossbreds $(\mathrm{P} \times \mathrm{O}, \mathrm{P} \times$ $\mathrm{V}, \mathrm{O} \times \mathrm{V})$ and reciprocals $(\mathrm{O} \times \mathrm{P}, \mathrm{V} \times \mathrm{P}, \mathrm{V} \times \mathrm{O})$ were explored in this study. Meat colour is one of the factors which the consumer uses as a measure of acceptance. For example, a pink interior is considered desirable in a processed whereas a pink or reddish colour is highly undesirable in fully cooked poultry meat (Singh et al., 2021). In the present study, meat color findings suggested that the breast and thigh of the Ovambo chicken genotype were paler (high $\mathrm{L}^{*}$ ), more yellow (high $\mathrm{b}^{*}$ ) and less red (low $a^{*}$ ) than other genetic groups. Potchefstroom Koekoek chicken genotype had higher values in all color indicators, $\mathrm{L}^{*}$ (lightness), $\mathrm{a}^{*}$ (redness), and $\mathrm{b}^{*}$ (yellowness) as compared to the other chicken breeds. It was however observed that the Venda breed had a high $\mathrm{L}^{*}$ (lightness) which was normal between 43 and 53. The $\mathrm{pH}$ of chicken meat for the current study was a significant source of variability amongst the nine genetic groups at different hours ( 2 hours, 24 hours) after slaughter. The $\mathrm{pH}$ declined in all the nine genetic groups at 2 to 24 hours with the exception of crossbred, $\mathrm{P} \times \mathrm{O}$ which increased from 6.06 to 6.38 . The tenderness of the meat was also examined with a Warner-Bratzler shear force. The Warner-Bratzler shear force is an objective measure of tenderness used in the research laboratory to evaluate relative differences in tenderness or toughness of meat products (Wang et al., 2019). The results of the present study indicated that shear force values of breast muscle were higher than those of the thigh muscle. Similar results were also reported by Wang et al. (2019). Singh et al. (2021) compared the carcass characteristics of a slowgrowing crossbred broiler to a fast-growing broiler and found that the $\mathrm{pH}$ at 24-hour post-mortem was 5.88 for a fast-growing broiler and 5.74 for a slow-growing broiler. The breast color of the fast-growing broiler had a lightness $\left(\mathrm{L}^{*}\right)$ of 51.93 , a redness $\left(\mathrm{a}^{*}\right)$ of 208 , and a yellowness $\left(\mathrm{b}^{*}\right)$ of 4.97, while the slow-growing broiler had an $\left(\mathrm{L}^{*}\right)$ of 45.39 , an $\left(a^{*}\right)$ of 2.64 , and a $\left(b^{*}\right)$ of 3.84 , respectively. Mueller et al. (2020) studied the meat quality of two dualpurpose and one-layer hybrid chickens for 67 or 84 days compared to a slow-growing broiler. The results showed that the $\mathrm{pH}$ in the breast muscle ranged from 5.00 to 6.00 at 24 hours post mortem, while the breast colour ranged from 47.0 to 59.0 for $\mathrm{L}^{*}, 1.11$ to 3.33 for $\mathrm{a}^{*}$, and -0.22 to 1.06 for $^{*}$. Devatkal et al. (2019) recognized that the breast shear force of the slow-growing broiler was 11.09 and 12.47 for the fast-growing broiler. Mueller et al. (2018) indicated that the breast meat $\mathrm{pH}$ at 24-hour postmortem for Ross PM3 chicken was 6.25, Sasso S1 chicken 5.92, Lohmann Dual chicken 5.82, Belgian Malines chicken 5.91, Schweizerhuhu chicken 5.73, and Lohmann Brown Plus chicken 5.90, while the breast colour ranged from $L^{*} 49.0$ to 54.6 , $a^{*} 1.26$ to 3.58 , and $b^{*} 0.09$ to 0.72 , respectively. These studies are inconsistent with the current study and the variations might be due to different genotypes, age, nutrition, and environment. Tyasi et al. (2019) discovered that the Potchefstroom Koekoek chicken genotype had a positive influence on the general ability to combine and the crossbred between the Potchefstroom Koekoek and the Venda chicken genotype had a positive influence on the specific ability to combine, and thus suggested that the Potchefstroom Koekoek chicken genotype could possibly be used for crossbreeding with other indigenous chicken genotypes to improve growth traits.

\section{CONCLUSION}

Crossbreeding had a remarkable effect on meat colour, $\mathrm{pH}$, and tenderness in a diallel cross of the Potchefstroom Koekoek, Ovambo, and Venda chicken genotypes. The Potchefstroom Koekoek genotype had normal meat colour and $\mathrm{pH}$ whereas the Venda chicken genotype had tougher meat than other chicken genotypes. It is recommended that crossbreeding could be introduced to improve genetic effects on carcass quality traits.

\section{DECLARATION}

\section{Acknowledgments}

The authors would like to express their appreciation to the experimental farm worker at the University of Limpopo for their support in data collection.

\section{Author's contributions}

Thobela L Tyasi conducted the experiment, analyzed the data and wrote the manuscript. Jones W $\mathrm{Ng}$ 'ambi and David Norris designed and oversaw the running of the experiment.

\section{Competing interests}

The authors declare that they have no conflict of interest. 


\section{REFERENCES}

Alabi OJ, Ng'ambi JW, and Mbajiorgu EF (2020). Aqueous extract of moringa (moringa oleifera) leaf (aemol) on the growth, sensory and histology parameters of broiler chickens. Applied Ecology and Environmental Research, 18(5): 6753-6764. DOI: https://www.doi.org/10.15666/aeer/1805_67536764

Devatkal S, Naveena B, and Kotaiah T (2019). Quality, composition, and consumer evaluation of meat from slow-growing broilers relative to commercial broilers. Poultry Science, 476(98): 6177-6186. DOI: http://dx.doi.org/10.3382/ps/pez344

Khalil MH, and Khadiga GA (2020). Analysis of diallel crossbreeding in chickens by REML and ANOVA methods. Egyptian Poultry Science Journal, 40(3): 663-671.

DOI: https://www.doi.org/10.21608/epsj.2020.115966

Manyelo TG, Selaledi L, Hassan ZM, and Mabelebele M (2020). Local chicken breeds of Africa: their description, uses and conservation methods. Animals, $\quad 10$ : $2257 . \quad$ DOI: https://www.doi.org/10.3390/ani10122257

Mueller S, Kreuzer M, Siegrist M, Mannale K, Messikommer RE, and Gangnat IDM (2018). Carcass and meat quality of dual-purpose chickens (Lohmann Dual, Belgian Malines, Schweizerhuhn) in comparison to broiler and layer chicken types. Poultry Science, 97: 3325-3336. DOI: http://dx.doi.org/10.3382/ps/pey172

Mueller S, Taddei L, Albiker D, Kreuzer M, Siegrist M, Messikommer R, and Gangnat I (2020). Growth, carcass, and meat quality of 2 dual-purpose chickens and a layer hybrid grown for 67 or $84 \mathrm{D}$ compared with slow-growing broilers. Journal of Applied Poultry Research, 29: 185-548. DOI: https://www.doi.org/10.1016/j.japr.2019.10.005

Mutibvu T, Chimonyo M, and Halimani TE (2020). Effect of strain, sex and rearing system on carcass and fat yield of naked neck, ovambo and potchefstroom koekoek chickens. Indian Journal of Animal Research, 54(9): 1171-1175. DOI: https://www.doi.org/10.18805/ijar.B-944

Singh M, Lim AJ, Muir WJ, and Groves PJ (2021). Comparison of performance and carcass composition of a novel slow-growing crossbred broiler with fastgrowing broiler for chicken meat in Australia. Poultry Science, Article in press. DOI: https://www.doi.org/10.1016/j.psj.2020.12.063

Tyasi TL, Norris D, Ng'ambi JW, and Mabelebele M (2019). Combining abilities and heterosis of body weight in a diallel cross from three South African indigenous chicken genotypes. Applied Ecology and Environmental Research, 17(4): 9717-9723. DOI: https://www.doi.org/10.15666/aeer/1704_97179723

Wang B, Du Y, Shen Q, Liu X, Xie C, Geng Z, and Chen $X$ (2019). Comparative study of growth performance and meat quality of three-line crossbred commercial group from Shanzhongxian and W-line chicken. Italian Journal of Animal Science, 18(1): 63-69. DOI:

https://www.doi.org/10.1080/1828051X.2018.14827 $\underline{97}$ 